\title{
HIDROLISA KOLAGEN DALAM CEKER AYAM HASIL PERENDAMAN DENGAN ASAM ASETAT PADA PROSES PEMBUATAN GELATIN
}

\author{
Herry Santosa*, Noer Abyor H, Nurmy Lailati Guyana, Sigit Firman Dwi Handono \\ Departemen Teknik Kimia Fakultas Teknik \\ Universitas Diponegoro Semarang \\ Jalan Prof. Sudharto, SH Tembalang Semarang \\ Penulis korespondensi: hersantos@undip.ac.id
}

\begin{abstract}
Herry Santosa, Noer Abyor H, Nurmy Lailati Guyana, Sigit Firman Dwi Handono, Gelatin is a chemical compound with molecular formula $\left(\mathrm{C}_{102} \mathrm{H}_{151} \mathrm{~N}_{31} \mathrm{O}_{39}\right)_{n}$ in the form of a heterogeneous mixture of polypeptide obtained by collagen partial hydrolysis of animal binding tissue by acid or base treatment. Sources of gelatin production generally derived from cow bones, pig skins, fish scales or chicken bones. Gelatin is widely used in food and pharmaceutical industries because of its ability to form a thermoreversible gel, among others as a stabilizer on ice cream, capsule making materials and matrix for implants. The main objective of this research is to make gelatin with chicken claw based ingredients through the process of collagen hydrolysis. Specifically aims to determine the effects of acetic acid concentration on the collagen levels, determining the most influential variable between temperature and time on the hydrolysis process, as well as the assessment and determination of the optimum temperature or time in the hydrolysis process so as to approximate the criteria corresponding to the commercial gelatin characteristics, i.e gel strength (50-300 Bloom), viscosity (1.5-7,5 cP), and gelatin sensory properties. To answer that goal, the research is planned through 2 stages, namely the preparation stage, product creation, and gelatin flour characterization. The preparatory stage consists of cleansing, reduction of chicken claw and demineralization. The production stage consists of determining the most influential variables and the optimum variable variations (temperature and time) of the collagen hydrolysis process into gelatin flour based on the functional properties and gelatin sensory properties. The results of this research showed that the optimum concentration of acetic acid in demineralization was at a concentration of 1.5 $N$, the most influential variable was the temperature variable with a single effect average value - 5.05, the relatively good variable collagen hydrolysis was at $60^{\circ} \mathrm{C}$ and 4 hour.
\end{abstract}

Keywords: gelatin, collagen, chicken claw, hydrolysis

\section{PENDAHULUAN}

Gelatin adalah senyawa kimia dengan rumus molekul $\left(\mathrm{C}_{102} \mathrm{H}_{151} \mathrm{~N}_{31} \mathrm{O}_{39}\right)_{\mathrm{n}}$ dan merupakan campuran heterogen polipeptida (senyawa pembentuk protein) yang diperoleh melalui hidrolisa parsial kolagen dari jaringan ikat hewan dengan perlakuan asam atau basa $^{[1]}$. Gelatin bersifat larut dalam air dan dapat membentuk thermoreversible gel yang bisa meleleh pada suhu yang lebih rendah dibandingkan dengan suhu tubuh manusia. Sifat tersebut menyebabkan gel gelatin banyak dimanfaatkan pada industri makanan maupun farmasi.

Beberapa aplikasi gelatin yaitu, sebagai plastik alternatif (edible film), zat pengikat, bahan stabilisasi dan teksturisasi pada susu maupun es krim, matriks untuk implan, bahan pembuatan kapsul, dan infus intravena ${ }^{[2]}$.

Kegunaan gelatin yang beragam menyebabkan tingginya jumlah permintaan untuk gelatin. Hal ini tidak seimbang dengan jumlah produksi gelatin dalam negeri. Untuk dapat memenuhi kebutuhan tersebut, gelatin di Indonesia masih mengandalkan impor. Impor gelatin pada Februari 2014 sebesar $601.681 \mathrm{~kg}^{[3]}$. Sumber bahan baku gelatin dapat berasal dari sapi (tulang dan kulit jangat), babi (kulit), ikan (sisik dan kulit), ayam (tulang), dan lain sebagainya ${ }^{[3]}$. Namun jenis gelatin yang populer dan banyak diproduksi di luar negeri adalah jenis gelatin yang bersumber dari kulit babi $(46 \%)$ dan sapi $(23,1 \%)^{[4]}$. Masalah yang timbul kemudian yaitu mengenai penerimaan masyarakat Indonesia terhadap jenis sumber bahan baku tersebut.

Oleh karena itu diperlukan sebuah upaya pengolahan atau rekayasa produk sehingga dapat menyajikan alternatif sumber gelatin yang dapat diterima oleh masyarakat secara lebih luas. Salah satu alternatif yang berpotensi sebagai bahan baku gelatin adalah ceker ayam. Ceker ayam tersedia cukup banyak karena tingkat konsumsi daging ayam pada masyarakat Indonesia cukup tinggi, tetapi tidak seluruhnya menyukai bagian ceker ayam. Secara agregat perkembangan konsumsi protein hewani khususnya dari daging ayam (ras) per kapita masyarakat Indonesia cenderung terus meningkat sebesar $2,27 \%$ per tahun ${ }^{[5]}$. Selain itu, potensi penggunaan ceker ayam sebagai bahan pembuatan gelatin dikarenakan kandungan kolagen pada ceker ayam sekitar 12,08\% [6]. Maka dengan adanya senyawa kolagen yang terdapat dalam ceker ayam, dimungkinkan dapat menghasilkan gelatin dengan kualitas yang hampir memenuhi SNI dan dapat diaplikasikan sebagai bahan tambahan pada proses produksi es krim. 
Penggunaan tulang ayam sebagai bahan baku pembuatan gelatin terbilang masih jarang dilakukan. Selain itu, belum ada spesifikasi mengenai bagian tulang mana yang digunakan dalam penelitian tersebut. Berdasarkan pertimbangan di atas, maka perlu dilakukan penelitian tentang kemampuan tulang ayam sebagai bahan baku pembuatan gelatin, khususnya pada bagian ceker ayam yang ditinjau secara kuantitatif dan uji kualitas. Selain itu, perlu dilakukan penelitian hingga pada tahap pembuatan tepung gelatin.

Tujuan dilaksanakannya penelitian ini secara umum adalah untuk membuat gelatin dengan bahan dasar ceker ayam. Tujuan secara khusus penelitian ini adalah Menentukan pengaruh konsentrasi asam asetat terhadap kadar kolagen dalam ceker ayam, menentukan variabel yang paling berpengaruh antara suhu dan waktu terhadap proses hidrolisa berdasarkan nilai rendemen, dan mengkaji serta menentukan suhu atau waktu optimum pada proses hidrolisa sehingga mendekati kriteria yang sesuai dengan karakteristik gelatin komersial berdasarkan: (a) Sifat fungsional dan viskositas (b) Sifat sensorik yang meliputi warna, bentuk, dan tekstur gelatin.

Adapun manfaat dari penelitian ini adalah data hasil penelitian dan metode pembuatan gelatin dari ceker ayam dapat dijadikan referensi atau acuan bagi para peneliti dan para pelaku usaha dalam mengembangkan penelitian selanjutnya dan bisnis di bidang pangan, didapatkan hasil berupa metode pembuatan gelatin dari ceker ayam dan variabelvariabelnya yang mampu memberikan hasil optimum dan relatif baik ditinjau dari analisis data yang didapat selama proses penelitian yang dapat mengatasi permasalahan ketahanan pangan di Indonesia, khususnya tepung gelatin.

\section{BAHAN DAN METODE}

Bahan yang digunakan adalah Ceker ayam, asam asetat $96 \%$, dan aquadest. Penelitian ini dilakukan melalui 2 tahapan utama yaitu tahap persiapan bahan baku dan tahap pembuatan tepung gelatin.

Tahap persiapan bahan baku dimulai dari ceker ayam dicuci air bersih, dipotong menjadi ukuran yang $\pm 2 \mathrm{~cm}$ dan didemineralisasi, direndam menggunakan larutan asam asetat $(0,1,0,5,1 \ldots) \mathrm{N}$ selama 24 jam dengan perbandingan w/v 1:3 menjadi ossein. Ossein ditambahkan larutan aquades untuk menjaga $\mathrm{pH}$ 6-7 dan ditiriskan. Hasil demineraisasi pada tiap variabel konsentrasi asam asetat dihidrolisa dan dibuat menjadi tepung gelatin. Tepung gelatin diuji kadar abunya untuk menentukan konsentrasi asam asetat yang optimum pada proses demineralisasi yang menghasilkan kadar abu pada gelatin sesuai ketentuan SNI (kadar abu gelatin maksimal 3,25\%). Hasil konsentrasi asam asetat yang didapat kemudian dijadikan variabel tetap pada demineralisasi untuk proses pembuatan tepung gelatin dengan variabel berubah suhu dan waktu hidrolisa.

Tahap pembuatan produk gelatin dimulai dari Ceker ayam yang telah didemineralisasi pada konsentrasi asam asetat optimum dihidrolisa menggunakan $\mathrm{H} 2 \mathrm{O}$ di dalam reaktor sesuai variasi perkakuan suhu $(60 \text { dan } 80)^{\circ} \mathrm{C}$ dan waktu hidrolisa (4 dan 6) jam, perbandingan mol kolagen dan air yaitu 1:2. Filtrat gelatin yang terbentuk disaring menggunakan kertas saring, dipekatkan di dalam evaporator pada suhu $70^{\circ} \mathrm{C}$ selama 12 jam kemuadian didinginkan dalam refrigerator $5-10^{\circ} \mathrm{C}$ selama 30 menit. Gelatin dituang ke dalam wadah dan dikeringkan dalam oven pada suhu $60^{\circ} \mathrm{C}$ selama 48 jam atau sampai kering. Lapisan gelatin yang terbentuk pada wadah diangkat dan dihaluskan untuk menghasilkan tepung gelatin.

Tepung Gelatin yang telah didapat dilakukan pengujian secara kualitatif dengan penambahan kalium dikromat. Tepung gelatin juga diuji secara kuantitatif melalui penetapan kadar nitrogen untuk mengdapatkan nilai rendemen $(\%)$. Nilai rendemen dapat ditentukan dengan menggunakan metode AOAC (1995)

Rendemen $(\%)=[($ berat gelatin hasil uji kuantitatif $)$ / (berat bahan baku) ] x 100\%

Data hasil kadar \% rendemen dibandingkan dan ditentukan kondisi operasi (suhu dan waktu ) optimumnya. Tepung gelatin yang didapat dari kondisi operasi optimum diuji kualitasnya menggunakan parameter pengujian antara lain kekuatan gel, viskositas gelatin, dan uji sensorik (warna, bentuk dan tekstur gelatin).

Tepung gelatin yang akan diuji viskositasnya diukur viskositasnya dengan menggunakan alat brookfoeld LV. Tepung Gelatin yang akan diuji kekuatan gelnya diukur menggunakan uji kekuatan gel (DIGITAL force gauge Model GY4). Pengujian sensorik tepung gelatin (warna, bentuk dan tekstur gelatin) digunakan metode uji kesukaan (hedonik) oleh 10 panelis.

\section{HASIL DAN PEMBAHASAN}

\section{Pengaruh dan Penentuan Konsentrasi Asam asetat terhadap kadar Abu dalam gelatin}

Proses demineralisasi dimaksudkan untuk menurunkan kadar abu gelatin dengan harapan agar didapatkan gelatin hingga memenuhi syarat gelatin yang sesuai dengan standar gelatin komersial ${ }^{[7]}$. Demineralisasi dilakukan pada kondisi operasi hidrolisa tetap (suhu $60^{\circ} \mathrm{C}$ dan waktu 4 jam) sedangkan konsentrasi asam asetat divariasi. hasil percobaan dapat dilihat dari Tabel 1. 
Tabel 1. Penentuan konsentrasi asam asetat optimum pada proses demineralisasi

\begin{tabular}{ccc}
\hline No & $\begin{array}{c}\text { Konsentrasi Asam } \\
\text { Asetat } \\
\text { Demineralisasi ( N) }\end{array}$ & $\begin{array}{c}\text { Kadar Abu } \\
(\%)\end{array}$ \\
\hline 1 & 0 & 8,25 \\
2 & 0,1 & 7,35 \\
3 & 0,5 & 7,02 \\
4 & 1 & 6,6 \\
5 & 1,5 & 2,5 \\
\hline
\end{tabular}

Berdasarkan Tabel 1 ketika konsentrasi asam asetat diperbesar dari $0 ; 0,1 ; 0,5 ; 1 ; \ldots ; \mathrm{N})$ terjadi penurunan kadar abu pada gelatin, hal ini dikarenakan pada proses demineralisasi terjadi pelunakan tulang sehingga kolagen yang terdapat pada bahan baku akan lebih mudah dihidrolisa ${ }^{[8]}$. Demineralisasi terjadi pemutusan ikatan kolagen dari garam kalsium dan penguraian kolagen triple heliks menjadi rantai tunggal sehingga pada waktu yang sama jumlah kolagen yang terhidrolisis lebih banyak [9].

Berdasarkan data diatas, untuk mendapatkan kadar abu yang sesuai dengan standar gelatin komersial SNI maka proses demineralisasi lebih baik dilakukan pada konsentrasi $1,5 \mathrm{~N}^{[7]}$.

Penentuan variabel yang paling berpengaruh antara suhu dan waktu terhadap proses hidrolisa berdasarkan nilai rendemen

Penentuan variabel yang paling berpengaruh dilakukan pada kondisi tetap konsentrasi asam asetat demineralisasi $1,5 \mathrm{~N}$, sedangkan suhu dan waktu hidrolisa divariasi (Tabel 2). Hasil olah data didasarkan interaksi antara suhu dan waktu hidrolisa dengan cara factorial design metode Quicker dinyatakan dalam Tabel 3. Selanjutnya perhitungan efek tunggal dan efek interaksi variabel seperti pada Tabel 4-6.

Tabel 2. Penentuan variabel paling berpengaruh pada proses hidrolisa

\begin{tabular}{cccc}
\hline & \multicolumn{2}{c}{ Variabel } & Rendemen \\
\cline { 2 - 3 } No & Suhu( $\left.{ }^{\mathbf{0}} \mathbf{C}\right)$ & Waktu(Jam) & \\
\hline 1 & 60 & 4 & 28,08 \\
2 & 60 & 6 & 27,78 \\
3 & 80 & 4 & 23,09 \\
4 & 80 & 6 & 22,76 \\
\hline
\end{tabular}

Tabel 3. Pemetaan Factorial Design untuk menentukan variabel suhu dan waktu hidrolisa kolagen

Faktor (Variabel)

\begin{tabular}{ccccc} 
No & & & $\begin{array}{c}\text { Kom- } \\
\text { binasi }\end{array}$ & $\begin{array}{c}\text { Respon } \\
\text { (\% Rendemen) }\end{array}$ \\
& Suhu (T) & $\begin{array}{c}\text { Waktu } \\
(\boldsymbol{\theta})\end{array}$ & & \\
\hline 1 & 60 & 4 & $(1)$ & 28,08 \\
2 & 60 & 6 & $\theta$ & 27,78 \\
3 & 80 & 4 & $\mathrm{~T}$ & 23,09 \\
4 & 80 & 6 & $\mathrm{~T} \theta$ & 22,76 \\
\hline
\end{tabular}

Tabel 4. Perhitungan efek tunggal variabel suhu (T) hidrolisa

\section{Kondisi Waktu konstan pada perubahan Suhu} (T)
Efek perubahan suhu dari $60^{\circ} \mathrm{C}$ menjadi $80^{\circ} \mathrm{C}$

\begin{tabular}{|c|c|}
\hline 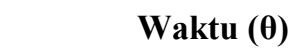 & \\
\hline 6 & $27,78-22,76=5,02$ \\
\hline 4 & $28,08-23,09=4,99$ \\
\hline $\begin{array}{c}\text { Rata - rata nilai efe } \\
\text { Suhu }(\mathrm{T})\end{array}$ & $(5,02+4,99) / 2=5,05$ \\
\hline
\end{tabular}
$(5,02+4,99) / 2=5,05$

Tabel 5. Perhitungan efek tunggal variabel waktu $(\theta)$ hidrolisa

\begin{tabular}{cc}
$\begin{array}{c}\text { Kondisi suhu konstan } \\
\text { pada perubahan } \\
\text { Waktu ( } \boldsymbol{\theta})\end{array}$ & $\begin{array}{c}\text { Efek perubahan waktu } \\
\text { dari } 4 \text { jam menjadi 6 jam }\end{array}$ \\
\hline Suhu (T) & \\
\hline 60 & $28,08-27,78=0,3$ \\
80 & $23,09-22,76=0,33$ \\
\hline $\begin{array}{c}\text { Rata - rata nilai efek } \\
\text { tunggal Waktu }(\theta)\end{array}$ & $(0,33+0,3) / 2=0,315$ \\
\hline
\end{tabular}

Tabel 6. Perhitungan efek interaksi suhu (T) dan waktu $(\theta)$ hidrolisa

\begin{tabular}{c}
$\begin{array}{c}\text { Nilai efek interaksi suhu }(\mathbf{T}) \\
\text { dan Waktu }(\boldsymbol{\theta})\end{array}$ \\
\hline$[(22,76+28,08) / 2]-[(27,78+23,09) / 2]=-$ \\
0,015 \\
\hline
\end{tabular}

Berdasarkan pengolahan data nilai rendemen diatas, didapatkan rata - rata nilai efek tunggal kondisi waktu konstan pada perubahan suhu sebesar 5,05 sedangkan rata - rata nilai efek tunggal kondisi suhu konstan pada perubahan waktu, sebesar 0,315, sehingga variabel suhu merupakan variabel yang 
paling berpengaruh dalam proses hidrolisa karena memiliki rata - rata efek tunggal dengan nilai positif paling besar $^{[10]}$.

\section{Optimasi Variabel Paling Berpengaruh}

Otimasi variabel paling berpengaruh dilakukan pada kondisi operasi tetap (konsentrasi asam asetat demineralisasi 1,5 $\mathrm{N}$ dan waktu hidrolisa 4 jam). Hasil percobaan dapat dilihat pada Tabel 7 .

Tabel 7. Menentukan kondisi relatif baik dengan suhu sebagai variabel paling berpengaruh

\begin{tabular}{ccc}
\hline & \multicolumn{2}{c}{ Variabel Respon } \\
\cline { 2 - 3 } No & Suhu $\left({ }^{\circ} \mathbf{C}\right)$ & Viskositas (cpoise) \\
\hline 1 & 60 & 1,7 \\
2 & 70 & 2,0 \\
3 & 80 & 1,48 \\
\hline
\end{tabular}

Berdasarkan Tabel 7, pada suhu hidrolisa $60^{\circ}$ C waktu 4 jam didapatkan viskositas sebesar 3,84 centipoise dan kekuatan gel sebesar 250 gbloom sedangkan pada suhu hidrolisa $80^{\circ} \mathrm{C}$ waktu 4 jam didapatkan viskositas sebesar 2,68 centipoise dan kekuatan gel sebesar 200 gbloom. Kedua variabel telah memenuhi standar gelatin komersial, akan tetapi variabel $60^{\circ} \mathrm{C} 4$ jam memiliki kadar protein yang lebih tinggi sebesar $28,08 \%$ sehingga kondisi relatif baik dengan suhu sebagai variabel paling berpengaruh adalah pada suhu hidrolisa $60^{\circ} \mathrm{C}$ dan waktu 4 jam, karena semakin tinggi suhu hidrolisa mengakibatkan protein yang terdapat dalam ceker ayam terdenaturasi sehingga gelatin yang dihasilkan memiliki kualitas yang lebih buruk ${ }^{[11]}$.

Gelatin yang didapat dari kondisi relatif baik dari suhu yang paling berpengaruh pada proses hidrolisa berdasarkan karakterisitik gelatin yang mendekati SNI kemudian dilakukan pengujian sensoriknya. Pengujian dilakukan menggunakan metode uji kesukaan (hedonik) dengan 10 panelis dengan membandinggan karakter sensorik gelatin hasil percobaan dengan gelatin komersial berdasarkan parameter warna, bentuk dan tekstur gelatin. Pengujian karakter sensorik gelatin disajikan dalam Tabel 8.

Dari Tabel 8. didapatkan bahwa rata - rata hasil uji sensorik produk gelatin hasil penelitian dengan parameter warna bau dan tekstur mendekati 0 hasil penelitian yang sedikit lebih gelap dan bau yang sedikit lebih menyengat, hal ini dikarenakan bahan baku pembuatan gelatin yang dibuat berasal dari ceker ayam sedangkan bahan baku gelatin komersial dibuat dari sumsum dan jaringan ikat sapi sehingga dengan perbedaan penggunaan bahan baku sifat sensorik dari gelatin juga akan sedikit berbeda.
Tabel 8. Tabel Uji Karakter Sensorik (Organoleptik) Gelatin Hasil Percobaan dibanding Gelatin Komersial

\begin{tabular}{ccccc}
\hline \multirow{2}{*}{ No } & \multicolumn{3}{c}{$\begin{array}{c}\text { Organoleptik Gelatin Ceker } \\
\text { Ayam }\end{array}$} & $\begin{array}{c}\text { Komen- } \\
\text { tar }\end{array}$ \\
\cline { 2 - 4 } & Warna & Bau & Tekstur & \\
\hline 1 & 3 & 3 & 4 & \\
2 & 3 & 3 & 4 & Warna \\
3 & 3 & 3 & 4 & sedikit \\
4 & 3 & 4 & 4 & lebih tua, \\
5 & 3 & 3 & 4 & tekstur \\
6 & 2 & 2 & 3 & hampir \\
7 & 2 & 2 & 3 & sama, \\
8 & 3 & 2 & 3 & aroma \\
9 & 3 & 3 & 3 & sedikit \\
berbeda \\
10 & 2 & 2 & 3 & \\
\hline
\end{tabular}

\section{KESIMPULAN}

Konsentrasi asam asetat optimum untuk demineralisasi ceker ayam adalah pada konsentrasi 1,5 $\mathrm{N}$ dengan kadar abu 2,5\%, variabel relatif baik pada proses hidrolisa kolagen adalah variabel suhu dengan nilai rata - rata efek tunggal poitif yang paling besar yaitu sebesar $-5,05$ dan variabel optimal yang paling berpengaruh pada proses hidrolisa kolagen adalah pada variabel suhu $60^{\circ} \mathrm{C}$ dan waktu 4 jam dengan nilai viskositas 3,8 centipoise dan kekuatan gel 250 gbloom. Sifat sensorik Gelatin hasil penelitian sudah hampir mendekati gelatin komersial.

\section{DAFTAR PUSTAKA}

1. Syafiqoh, F. (2014). Analisis Gelatin Sapi dan Gelatin Babi pada Produk Cangkang Kapsul Keras Obat dan Vitamin Menggunakan FTIR dan KCKT. Jakarta: UIN Syarif Hidayatullah.

2. Ahmad, T., Ismail, A., Ahmad, S. A., Khalil, K. A., Kumar, Y., Adeyemi, K. D., \& Sazilli, A. Q. (2017). Recent Advances on The Role of Process Variables Affecting Gelatin Yield and Characteristics with Special Reference to Enzymatic Extraction: A Review. Food Hydrocolloids, 63, 85-96.

3. BPS. (2016). Statistik Perdagangan Luar Negeri. Jakarta: Badan Pusat Statistik.

4. Karim, A., \& Bhat, R. (2009). Fish Gelatin: Properties, Challenges, and Prospects as an Alternative to Mammalian Gelatins. Food Hydrocolloids, 23, 563-576.

5. Kementerian Pertanian. (2015). Outlook Komoditas Pertanian Sub Sektor Peternakan Daging Ayam. Pusat Data dan Sistem Informasi Pertanian Sekretariat Jenderal Kementrian Pertanian 2015, Jakarta.

6. Hashim, P., Ridzwan, M. S., \& Bakar, J. (2014). Isolation and Characterization of Collagen from Chicken Feet. International Journal of 
Bioengineering and Life Sciences, 8(3), 250254.

7. Dewan Standardisasi Nasional. (1995). SNI 063735-1995. Mutu dan Cara Uji Gelatin. Dewan Standardisasi Nasional, Jakarta

8. Amiruldin, M. (2007). Pembuatan gelatin dan analisis karakteristik gelatin dari tulang ikan tuna (Thunnus albacares). Fakultas Teknologi Pertanian Institut Pertanian Bogor, Bogor

9. Utama, H. 1997. Gelati yang bikin heboh. Jurnal Halal. LPPOM_MUI. 18:10-12.
10. Iqbal, M., Anam, C., \& A, A. R. (2015). Optimasi Rendemen dan Kekuatan Gel Gelatin Ekstrak Tulang Ikan Lele Dumbo (Clarias gariepinus sp). Teknosains Pangan, 4(4), 8-15.

11. Fadillah, G., Putri, P., Azizah, N.L.N., Purbayanto, Y.O., Saraswati, T.E., (2013). Isolasi gelatin dari limbah ceker ayam sebagai alternatif bahan pengawet alami bahan makanan. Seminar Nasional Kimia Terapan Indonesia 2013, 2, 41-44. 